Ann. Biol. anim. Bioch. Biophys., 1977, 17 (2), 207-213.

\title{
Extraction of concanavalin A affinity material from rat testicular and epididymal spermatozoa
}

\author{
par Suzanne FOURNIER-DELPECH*, B. J. DANZO and Marie-Claire ORGEBIN- \\ CRIST \\ Department of Obsfefrics and Gynecology \\ Vanderbilt School of Medicine \\ Nashrille, Tennessee 37232, U. S. A.
}

\begin{abstract}
Summary. Immature and mature rat spermatozoa obtained by cannulation of the refe testis and the cauda epididymidis, respectively, have been labeled by the lactoperoxidase iodination technique. After solubilization with SDS or Triton X-100, the labeled glycoproteins have been fractionated by affinity chromatography using a Concanavalin A-agarose column. Comparison of the fractions eluted by methyl- $\alpha$-D-glucopyranoside after labeling of immature and mature spermatozoa revealed an increase in Concanavalin A binding sites on the spermatozoa during their passage through the epididymis.
\end{abstract}

\section{Introduction.}

Testicular spermatozoa are unable to fertilize ova ; this ability is gained while spermatozoa pass through the epididymis (for review, see Orgebin-Crist, 1975). It has been repeatedly suggested that changes in the macromolecular organization of the gamete membranes must precede this process of fertilization (for review, see Austin, 1975 ; Johnson, 1975).

In contrast with other cell types, there is relatively little information available about the macromolecular structure of the sperm membrane. Yet, this membrane, including substances absorbed to it during epididymal transit, appears to be intimately involved in the processes of sperm maturation, capacitation, and fertilization (Bedford, 1975). Biochemical characteristics of the sperm membrane which have been examined are the surface binding pattern of Concanavalin $A$ and other plant lectins and the surface binding pattern of colloidal iron hydroxyde particles (Edelman and Millette, 1971 ; Nicolson and Yanagimachi, 1972 ; Yanagimachi et al., 1973a, b ; Bedford et al., 1973 ; Nicolson and Yanagimachi, 1974 ; Morstin and Courot, 1974 ; Gordon ef al., 1974, 1975). Distinct local differences in these binding properties indiFrance.

* Present Address : Station de Physiologie de la Reproduction, I. N. R. A., Nouzilly, 37380 Monnaie, 
cate differences in charge densities and differences in the terminal saccharide residues on the plasma membrane of immature, mature, and capacitated spermatozoa.

The introduction of reagents which specifically react with externally disposed constituents of the plasma membrane provides a method for probing the cell surface. In this study the proteins associated with rat sperm membranes were labeled with [ $\left.{ }^{125}\right]$. The glycoprotein fraction was separated from the total pool of labeled proteins using Concanavalin A affinity chromatography. The amount of Concanavalin A affinity material in extracts of testicular and epididymal spermatozoa was compared.

\section{Materials and methods.}

Chemicals. [125]] $(500-750 \mathrm{mCi} / \mathrm{ml})$ were purchased from New England Nuclear Corporation. Sucrose and buffer grade Tris(base) were purchased from SchwarzMann. Insoluble Concanavalin A (Agarose) and lactoperoxidase were purchased from Amersham-Searle. All other chemicals were reagent or analytical grade.

Spermatozoa. Adult male rats of the Wistar strain were used. Testicular spermatozoa were obtained by cannulation of the rete testis as described by Tuck et al. (1970). Spermatozoa from the distal cauda were obtained from epididymal duct as described by Brooks ef al. (1974). The cells were washed twice by centrifugation in $15 \mathrm{ml}$ of cold phosphate buffer ( $\mathrm{pH}$ 7.5-0.05 M). The number of spermatozoa per aliquot of fluid was determined and the concentration was adjusted such that, in each experiment, a similar number of testicular and epididymal spermatozoa was labeled.

lodination. Packed and washed spermatozoa (5-30 $\times 10^{6}$ cells) were suspended in 1-2 $\mathrm{ml}$ of $0.05 \mathrm{M}$ phosphate buffer $\left(\mathrm{pH} \mathrm{7.5)}\right.$ and iodinated with $100 \mu \mathrm{Ci}\left[{ }^{125}\right]$ in the presence of lactoperoxidase. An aliquot $(200 \mu \mathrm{l})$ of the supernatant of the first wash was also iodinated. The iodination procedure is essentially that described by Hunt and Brown (1974) for isolated mouse cells, except that the enzymatic reaction was carried in phosphate buffer at $\mathrm{pH} 5.8$ rather than 7.5. The cells were recovered by centrifugation and washed with cold Tris buffer $(10 \mathrm{mM}$ Tris $-\mathrm{HCl}, 5 \mathrm{mM} \mathrm{MgCl}$, $5 \mathrm{mM}$ Dithiotreitol, $\mathrm{pH}$ 7.5) until the supernatant was free of radioactivity.

Solubilization of Sperm Proteins.

- SDS Solubilization. Packed and washed iodinated spermatozoa were resuspended in $0.1 \mathrm{ml}$ of a sodium duodecylsulfate solution (1 p. 100 SDS in $10 \mathrm{mM} \mathrm{Tris-HCl}$ buffer containing 2 p. 100 mercaptoethanol). Cells were incubated for 30 minutes at $80^{\circ} \mathrm{C}$, centrifuged at room temperature, and the supernatant transferred to a colomn of Concanavalin A agarose.

Triton X-100 Solubilization. Packed iodinated spermatozoa were washed four times in $0.05 \mathrm{M}$ phosphate buffer $\mathrm{pH} 7.5$ at $4^{\circ} \mathrm{C}$. The pellet was resuspended in acetate buffer $(0.1 \mathrm{M}$ aceto-acetic buffer, $1 \mathrm{mM} \mathrm{MgCl}, 1 \mathrm{mM} \mathrm{MnCl}, 1 \mathrm{mM} \mathrm{CaCl}, 1 \mathrm{M} \mathrm{NaCl}$, $\mathrm{pH}$ 5.1) containing 1 p. 100 Triton $X-100$. The spermatozoa were incubated in $1 \mathrm{ml}$ of the Triton solution for $30 \mathrm{~min}$. at $4{ }^{\circ} \mathrm{C}$. Following the incubation, the sample was centrifuged $(800 \times \mathrm{g}$ for $15 \mathrm{~min}$.) to sediment the particulate material. The supernatant was decanted and saved. The particulate material was reextracted twice. The supernatants were pooled and transferred to a column of Concanavalin A agarose. 
Separation of Glycoproteins by Agarose Concanavalin A Chromatography. The affinity of the carbohydrate moieties of glycoproteins for Concanavalin $A$ was used for the separation of these proteins from the rest of the iodinated sperm proteins. After solubilization with SDS or Triton X-100, the proteins were applied to the column, the column was washed with $15 \mathrm{ml}$ of aceto-acetic buffer until the eluate was free of radioactivity. The labeled glycoproteins were then eluted with the same buffer containing methyl$\alpha$-D-glucopyranoside (MeG) as described by Dufau et al. (1972). The elution of the Concanavalin A affinity material was performed in a step-wise fashion using $0.1 \mathrm{M} \mathrm{MeG}$ and $1.0 \mathrm{M} \mathrm{MeG}$.

\section{Results.}

After iodination of testicular and epididymal spermatozoa there was no significant difference in the total radioactivity per $10^{4}$ cells between the two types of cells (table 1). SDS extraction removed virtually all of the radioactivity from spermatozoa.

\section{TABLE 1}

Comparison of $\left[{ }^{125} \mathrm{I}\right]$ bound to total proteins in testicular and epididymal spermatozoa and bound to proteins having on affinity for Concanavalin A (Con A)

\begin{tabular}{lrrc}
\hline & $\begin{array}{c}\text { Testicular } \\
\text { Spermatozoa }\end{array}$ & $\begin{array}{c}\text { Epididymal } \\
\text { Spermatozoa }\end{array}$ & Significance \\
\hline $\begin{array}{l}\left.\text { Total Proteins. Cpm } / 10^{4} \text { Spermatozoa }{ }^{1}\right) \\
\begin{array}{l}\text { Con-A Affinity Material. Cpm/10 } \\
\text { tozoa }\left({ }^{2}\right)\end{array}\end{array}$ & $3900 \pm 575$ & $4950 \pm 623$ & N. S. \\
\hline
\end{tabular}

(1) $\bar{X} \pm \operatorname{SEM}(\mathrm{N}=9)$

$\left({ }^{2}\right) \bar{X} \pm \operatorname{SEM}(N=7)$

When Triton X-100 was used 46 p. 100 of the total radioactivity was removed, 73 p. 100 of this was removed by the first extraction (table 2 ).

TABLE 2

Radioactivity extracted by Triton $X-100$ from labeled spermatozoa

\begin{tabular}{|c|c|c|c|c|}
\hline \multirow{3}{*}{$\begin{array}{c}\text { Total } \\
\text { Radioactivity }\left({ }^{1}\right)\end{array}$} & \multicolumn{4}{|c|}{ Radioactivity/0.5 MI supernatant } \\
\hline & \multirow{2}{*}{$\begin{array}{l}\text { Buffer } \\
\text { Alone }\end{array}$} & \multicolumn{3}{|c|}{$\begin{array}{l}\text { Buffer + Triton } 1 \text { p. } 100 \\
\text { Number of Washes }\left({ }^{2}\right)\end{array}$} \\
\hline & & 1 & 2 & 3 \\
\hline $9.2 \times 10^{6} \mathrm{cpm}$ & $200 \mathrm{cpm}$ & $3 \times 10^{6} \mathrm{cpm}$ & $0.7 \times 10^{6} \mathrm{cpm}$ & $0.5 \times 10^{6} \mathrm{cpm}$ \\
\hline
\end{tabular}

(1) $6.6 \times 10^{6}$ spermatozoa were present in the incubation.

(2) Each washing contained $0.6 \mathrm{ml}$. 
We verified that spermatozoa submitted to three extractions by Triton, as described on figure 2, are apparently intact under contrast phase microscopy. As in other cells, labeling is restricted to proteins on the sperm surface. The labeled glycoproteins with $\alpha$-D-mannose or $\alpha$-D-glucose residues were eluted from the pool of labeled membrane proteins in a single peak after agarose Concanavalin A chromatography.

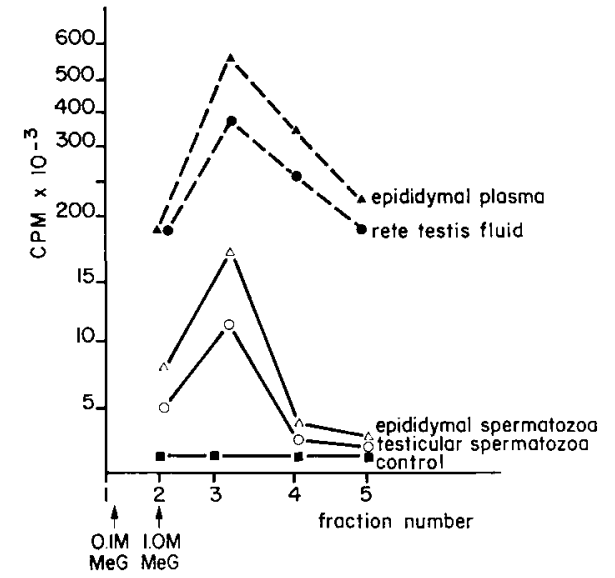

FIG. 1. - Elution of SDS solubilized sperm $\left[{ }^{125} \mathrm{I}\right]$ glycoproteins from a Concanavalin A Agarose column by methyl- $\alpha-D-g l u c o p y r a n o s i d e ~[M e G]$.

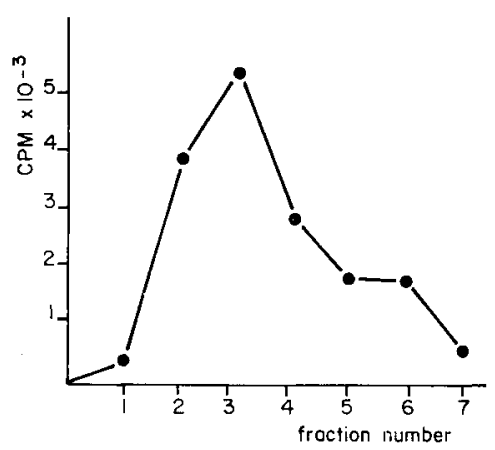

FIG. 2. - Elution profile of Triton X-100 solubilized [125]] glycoproteins of spermatozoo from a Concanavalin A Agarose column.

No difference was observed between the elution profiles of the glycoproteins extracted with Triton (fig. 2) or with SDS (fig. 1). Glycoproteins with affinity for Concanavalin A are found both in spermatozoa and in seminal plasma (fig. 1) ; but testicular spermatozoa contain significantly less glycoproteins with an affinity for Concanavalin $A$ than do epididymal spermatozoa (table 1). A preliminary analysis by sucrose gradient ultracentrifugation done following the technique previously described by Danzo ef al., 1972, suggests that the Concanavalin A affinity material has a sedimentation coefficient of 4-5S.

\section{Discussion.}

The iodination technique used in the study of plasma membrane of many cell types (Juliano and Behar-Bannelier, 1975) has been successfully extended to spermatozoa. The iodination conditions were very similar to those used by Hunt and Brown (1974) where lactoperoxidase is used to iodinate tyrosine residues of protein species present on the external surface of intact cells. Lavon (1971) studied the composition of amino acids contained in the lyophilized dry matter from immature and mature epididymal spermatozoa of the bull and found that the amount of tyrosine residues did not show a significant change during maturation. Thus, even though specific differences need to be considered further, our results from labeling of imma- 
ture and mature sperm are consistent with those of Lavon. Spermatozoa are not readily dissolved by agents known to solubilize other cell types. In particular, the outer mitochondrial membrane and the nuclear membrane are resistant to SDS treatment unless a reducing agent is added (Calvin and Bedford, 1971 ; HernandezMontes ef al., 1973). This peculiarity, however, permits, by sequential extraction with different solubilizing agents, the stripping of various sperm organelles. Treatment with 1 p. 100 SDS or 1 p. 100 Triton X-100 alone will remove the sperm plasma membrane (Wooding, 1973 ; Olson et al., 1975a, b) and permits the extraction of the externally disposed plasma membrane proteins labeled with [125l]. From table 2 we can conclude that an important part of the labeling is located on the sperm surface.

Specific adsorption of glycoproteins by plant lectins has been well documented (Nicolson, 1974). Concanavalin $A$ is specific for terminal saccharide residues similar to $\alpha$-D-glucose or $\alpha$-D-mannose ; its coupling with agarose permits the isolation and fractionation of labeled glycoprotein molecules with an affinity for Concanavalin A. Glycoproteins are known to be important constituents of cellular membranes. In addition to providing binding sites for antibodies, lectins, etc., they are also thought to be involved in intercellular recognition and adhesion (Roseman, 1974). Discrete receptor sites for several lectins have been identified on both the surface or spermatozoa and ova (Edelman and Millette, 1971 ; Nicolson and Yanagimachi, 1972 ; Gordon et al., 1974, 1975 ; Oikawa et al., 1974, Aketa, 1975 ; Nicolson et al., 1975 ; Yanagimachi and Nicolson, 1976). Differences in lectin binding sites between epididymal, ejaculated, and capacitated spermatozoa hove been found : a dense population of receptors for Concanavalin $A$ has been visualized by electron microscopy on the plasma membrane of mature epididymal spermatozoa, but not on immature and capacitated spermatozoa. The suggestion was made that the surface coat is not fully developed when spermatozoa enter the epididymis (Gordon et al., 1974, 1975). This development occurs during epididymal transit. The subsequent loss of Concanavalin A receptors during capacitation is suggestive of the functional importance of these changes in the sperm plasma membrane. In this investigation we have found that Concanavclin A receptors are present in the plasma membrane of rat testicular spermatozoa. They can be labeled, solubilized, and extracted. However, quantitatively, there are more binding sites in the membrane of mature spermatozoa from the cauda epididymidis. Gordon (1974) had observed that, although the majority of spermatozoa in the caput epididymidis lacks Concanavalin A receptors, a few spermatozoa had a thin irregular coating and very rarely a few spermatozoa had a surface coat characteristic of mature spermatozoa. From this description, which indicates the very rare occurrence of Concanavalin A receptors on the surface of spermatozoa from the caput, it seems unlikely that the Concanavalin A receptors biochemically extracted from testicular spermatozoa in this study could be the result of the heterogeneity of the sperm population. Our results suggest that discrete binding site for Concavalin A are present in the plasma membrane of testicular spermatozoa. Their number increases during epididymal transit, but their characteristics, as determined by sucrose density centrifugation and polyacrylamide gel electrophoresis, remain to be studied and compared with those of spermatozoa from the cauda. 
Acknowledgments. - The experiments were supported by the National Institutes of Health grants (HD 03820 and HD 05797) and the Population Council. One of us (S. F-D) was supported by a fellowship from the Délégation Générale à la Recherche Scientifique et Technique (France) and wishes to thank Pr Thibault, Dr Courot, and Mrs Garcia for their help and advice.

Résumé. Le spermatozoïde immature prélevé dans le rete testis ef le spermatozoïde fécondant de l'épididyme distal ont été marqués chez le Rat par I $^{125} \mathrm{Na}$ en présence de lactoperoxidase. Les glycoprotéines de surface ont été solubilisées par le SDS à $80^{\circ} \mathrm{C}$ ef par le triton et fractionnées sur colonne de Concanavaline A par chromatographie d'affinité. L'étude du complexe déplacé par l' $\alpha 2-D$-méthyl-glucose montre une augmentation des récepteurs Concanavaline $A$ du spermatozoïde au cours de la maturation intraépididymaire chez le Rat.

\section{References}

AKETA K., 1975. Physiological studies on the sperm surface component responsible for sperm-egg binding in sea urchin fertilization. Expll. Cell Res., 90, 56-62.

AUSTIN C. R., 1975. Membrane fusion events in fertilization. J. Reprod. Fertil., 44, 155-166.

BEDFORD J. M., 1975. Maturation, transport, and fate of spermatozoa in the epididymis, 303-317. In Handbook of Physiology, Vol. V, American Physiological Society.

BEDFORD J. M., CALVIN H., COOPER G. W., 1973. The maturation of spermatozoa in the human epididymis. J. Reprod. Fertil., Suppl. 18, 199-213.

BROOKS D. F., HAMILTON D. W., MALLEK A. H., 1974. Carnitine and glycerylphosphorylcholine in the reproductive tract of the male rat. J. Reprod. Fertil., 36, 141-160.

CALVIN H. I., BEDFORD J. M., 1971. Formation of disulphide bonds in the nucleus and accessory structures of mammalian spermatozoa during maturation in the epididymis. J. Reprod. Fertil., Suppl. 13, 65-75.

DANZO B. J., ORGEBIN-CRIST M.-C., TOFT D. O., 1973. Characterization of a cytoplasmic receptor for $5 \alpha$-dihydrotestosterone in the caput epididymidis of intact rabbits. Endocrinology, 92, 310-317.

DUFAU J. L., TSURUHARA T., CATT K. J., 1972. Interaction of glycoprotein hormones with agaroseconcanavalin A. Biochim. Biophys. Acfa, 278, 281-292.

EDELMAN G. M., MILLETTE C. F., 1971. Molecular probes of spermatozoa structures. Proc. Natl. Acad. Sci., 10, 2436-2440.

GORDON M., DANDEKAR P. V., BARTOSZEWICZ W., 1974. Ultrastructural localization of surface receptors for concanavalin A on rabbit spermatozoa. J. Reprod. Fertil., 36, 211-214.

GORDON M., DANDEKAR P. V., BARTOSZEWICA W., 1975. The surface coat of epididymal, ejaculated and capacitated sperm. J. Ultrastruct. Res., 50, 199-207.

HERNANDEZ-MONTES H., IGLESIAS G., MUJICA A., 1973. Selective solubilization of mammalian spermatozoa structures. Exptl. Cell Res., 76, 437-440.

HUNT R. C., BROWN J. C., 1974. Surface glycoproteins of mouse L cells. Biochemistry, 13, 22-28.

JOHNSON M. H., 1975. The macromolecular organization of membranes and its bearing on events leading up to fertilization. J. Reprod. Fertil., 44, 167-184.

JULIANO R. L., BEHAR-BANNELIER M., 1975. An evaluation of techniques for labelling the surface proteins of cultured mammalian cells. Biochim. Biophys. Acta, 375, 249-267.

LAVON U., VOLCANI R., DANON D., 1971. The proteins of bovine spermatozoa from the caput and cauda epididymidis. J. Reprod. Fertil., 24, 219-232.

MORSTIN J., COUROT M., 1974. Ultrastructure des spermatozoïdes de taureaux de différente fécondance. Morphologie ultrastructurale, glycoproteines acrosomiques et membranaires, charges négatives de surface. Ann. Biol. anim. Bioch. Biophys., 14, 581-590.

NICOLSON G. L., 1974. The interactions of lectins with animal cell surfaces. Intl. Rev. Cytol., 39, 89-190. 
NICOLSON G. L., YANAGIMACHI R., 1972. Terminal saccharides on sperm plasma membranes : identification by specific agglutinins. Science, 177, 276-279.

NICOLSON G. L., YANAGIMACHI R., 1974. Mobility and the restriction of mobility of plasma membrane lectin-binding components. Science, 184, 1294-1296.

NICOLSON G. L., YANAGIMACHI R., YANAGIMACHI H., 1975. Ultrastructural localization of lectin-binding sites on the zonae pellucidae and plasma membranes of mammalian eggs. J. Cell Biol., 66, 263-274.

OIKAWA T., NICOLSON G. L., YANAGIMACHI R., 1974. Inhibition of hamster fertilization by phytoagglutinins. Exptl. Cell Res., 83, 239-246.

OLSON G. E., HAMILTON D. W., FAWCETT D. W., 1976a. Isolation and characterization of the fibrous sheath of rat epididymal spermatozoa. Biol. Reprod., 14, 517-530.

OLSON G. E., HAMILTON D. W., FAWCETT D. W., 1976b. Isolation and characterization of the perforatorium of rat spermatozoa. J. Reprod. Fertil., 47, 293-297.

ORGEBIN-CRIST M.-C., DANZO B. J., DAVIES J., 1975. Endocrine control of the development and maintenance of sperm fertilizing ability in the epididymis, 319-338. In Handbook of Physiology, Vol. V, American Physiological Society.

ROSEMAN S., 1974. Complex carbohydrates and intercellular adhesion, 255-271. In The Cell Surface in Development, Chapter 13, John Wiley \& Associates, N. Y.

TUCK B. R., SETCHELL B. P., WAITES G. M. H., YOUNG J. A., 1970. The composition of fluid collected by micropuncture and catheterization from seminiferous tubules and rete testis of rats. Pflüg Arch. ges. Physiol., 318, 225-243.

YANAGIMACHI R., NICOLSON G. L., NODA Y. D., FUJIMOTO M., 1973a. Electron microscopic observations of the distribution of acidic anionic residues on hamster spermatozoc and eggs before and during fertilization. J. Ulfrastruct. Res., 43, 344-353.

YANAGIMACHI R., NODA Y. D., FUJIMOTO M., NICOLSON G. I., 1973b. The distribution of negative surface charges on mammalian spermatozoa. Am. J. Anat., 135, 497-520.

YANAGIMACHI R., NICOLSON G. L., 1976. Lectin-binding properties of hamster egg zona pellucida and plasma membrane during maturation and preimplantation development. Exptl. Cell Res., 100, 249-257.

WOODING F. B. P., 1973. The effect of triton $X-100$ on the ultrastructure of ejaculated bovine sperm. J. Ultrastruct. Res., 42, 502-516. 